Купчичев С. С.

СЦЕНИЧЕСКОЕ ТЕЛО (ЗАМЕТКИ К «ТЕАТРАЛЬНОЙ АНТРОПОЛОГИИ» Э. БАРБЫ И Н. САВАРЕЗЕ)

Белгородский государственный академический театр драмы им. М. С. Щепкина, Соборная пл., д. 1, г. Белгород 308000, Россия; shamansss@mail.ru

Аннотация. Почти десятилетие назад в российском культурно-философском пространстве появилось русское издание «Театральной антропологии» Э. Барбы и Н. Саварезе. Близкий юбилей соотносим с еще одной примечательной датой, сорокалетием Международной школы театральной антропологии, основанной Э. Барбой. Юбилейные заметки посвящены актуальным междисциплинарным смысловым структурам и доминантам энциклопедического издания - своего рода практической философии театрального действия. Анализ «Театральной антропологии» позволяет уточнить возможные границы действительных и действенных проявлений актерского существования, в широком спектре театральных практик. В качестве ключевого концепта «Театральной антропологии» исследуется понятие сценического тела, которое позволяет уточнить особую телесную свободу актерского действия, - на уровне простейших связностей тела, в их соотнесении с неустранимой свободой сценической ситуации. Следуя антропологическим построениям Э. Барбы и Н. Саварезе, представляется важным обратить внимание на «психофизический аппарат исполнителя», который в практике театрального представления может обретать качества, не свойственные ему в обычной жизни. Предложенные в «Театральной антропологии» известные или изысканные формы телесно-зрелищного искусства, как показывается в заметках, позволяют перейти от восприятия сценического поведения как необходимости что-то выражать к возможности увидеть в нем самостоятельную ценность - основания своего рода деятельной идентичности актерской работы.

Ключевые слова: Эудженио Барба; Никола Саварезе; театральная антропология; сценическое тело; принцип оппозиции; актерское присутствие; кодификация театрализованного зрелища

Для цитирования: Купчичев С.С. Сценическое тело (заметки к «Театральной антропологии» Э. Барбы и Н. Саварезе) // Научный результат. Социальные и гуманитарные исследования. 2019. Т. 5. № 2. C. 60-71. DOI: 10.18413/2408-932X-2019$5-2-0-8$

\title{
S. S. Kupchichev
}

STAGE BODY, OR JUBILEE NOTES TO "THEATER ANTHROPOLOGY" (RE)CONSTRUCTED BY EUGENIO BARBA AND NICOLA SAVARESE

Belgorod State Academic Drama Theater behalf of M. S. Schepkina, 1 Cathedral Sq., Belgorod 308000, Russia; shamansss@mail.ru

Abstract. The Russian edition of "Theater Anthropology" by E. Barba and N. Savarese almost a decade ago appeared in the philosophical space of Russian culture. The close anniversary is quite correlated with another remarkable date, the fortieth anniversary of 
the International School of Theater Anthropology, founded by E. Barba. The jubilee notes are devoted to current interdisciplinary semantic structures and dominants of the encyclopedic publication as a kind of practical philosophy of theatrical action. The analysis of "Theater Anthropology" clarifies the boundaries or the threshold senses of real and effective manifestations of acting, in a wide range of theatrical practices. The concept of the stage body allows to point to the special bodily freedom of acting, or the simplest connections of the body in their correlation with the ineradicable freedom of the stage situation. It seems important to pay attention to the "psychophysical apparatus" of "becoming performer" of Barba's anthropological performance; the quite refined forms of body-entertainment art proposed in "Theater Anthropology" seems allow not only to recognize any visual perceptions of stage behavior but to express a deep ontological dignity of theatrical action.

Keywords: Eugenio Barba; Nicola Savarese; theatrical anthropology; stage body; principle of opposition; acting presence; codification of the dramatized spectacle

For citation: Kupchichev S. S. (2019), "Stage body, or jubilee notes to "Theater anthropology' (re)constructed by Eugenio Barba and Nicola Savarese", Research Result. Social Studies and Humanities, 5 (2), 60-71, DOI: 10.18413/2408-932X-2019-5-2-0-8

\section{Актер и \\ «онтологический свидетель»}

В пьесе Тома Стоппарда «Розенкранц и Гильденстерн мертвы» есть такой эпизод: актер, встретив в Эльсиноре Розенкранца и Гильденстерна, которые до этого, будучи единственными зрителями, бросили (не совсем по своей воле) его бродячую труппу посреди представления, на почве уязвленного самолюбия разражается монологом, начинающимся словами: «Мы - актеры, мы нечто обратное людям! <..> мы отказались от самих себя, как требует наша профессия, - уравновесив это дело мыслью, что кто-то на нас смотрит» (Стоппард). Это патетическое, мистифицирующее заявление можно уточнить двумя совершенно житейскими, обывательскими наблюдениями, из тех, которые обычно не принято обсуждать, настолько они очевидны.

Первое - грубое, я бы даже назвал его мужским. Театр отличается последовательно неадекватным поведением людей на сцене: они утрированно говорят или двигаются, просто много двигаются, или, наоборот, застывают на месте и произносят длиннейшие монологи, изображают некую флору или фауну, начинают танцевать или петь без видимой причины, при- нимают противоестественные позы, бросаются в истерику, поминутно плачут, хохочут, кричат, да просто строят рожи, наконец. С точки зрения житейской логики такое поведение избыточно и бессмысленHо.

Второе - несколько мечтательное, что ли. Сценическую ситуацию можно охарактеризовать так: кто-то что-то делает только потому, что на него в данный момент смотрят. Пассивная (на первый взгляд), необязательная позиция обязывающего к действию наблюдателя выступает как нечто первичное, онтологическое по отношению к, зачастую, очень активному взаимодействию. Само по себе это взаимодействие не событийно, оно ничто, и лишь тогда начинает обретать плоть, когда «включается» в событие-взгляд. Забавно провести мысленный эксперимент, представив, что в разгар спектакля зрители, все как один, встали и покинули представление. Фантазия рисует достаточно уморительную картину с одной стороны, и - совершенно уничтожающий, травмирующий акт, с другой - со стороны исполнителей. Призовем стоппардовского актера с его красноречием в помощь и позволим закончить свой монолог: «И вот, как несмышленые дети, приплясывая, в одежде, которую 
никто не носит, твердя слова, которых никто не говорит, в дурацких париках, клянясь в любви, распевая куплеты, убивая друг друга деревянными мечами, впустую вопя о потерянной вере после пустых клятв отмщения - и каждый жест, каждая поза растворялись в прозрачном, необитаемом воздухе <..> Пока продолжался длинный монолог убийцы, мы, не смея шелохнуться, застыв в своих позах, сначала с надеждой, потом с неуверенностью, потом уже в полном отчаянии обшарили глазами каждый куст, каждый бугорок, каждый угол - но вас нигде не было. Потом головы зашевелились, шеи стали вытягиваться - осторожно, как у ящериц, труп невинной Розалинды подал признаки жизни, и король запнулся. Даже тогда сила привычки и упорная надежда, что наша публика всё-таки следит за нами из-за какого-нибудь куста, еще долго заставляла тела наши бессмысленно двигаться, рты раскрываться - хотя уже ни складу ни ладу не было, - пока всё это, как телега о камень, не споткнулось о тишину. Никто не подошел. Никто нас не окликнул. Тишина была ненарушимой, гнетущей, бесстыдной. Мы сняли наши короны, и мечи, и 30лотое тряпье и молча двинулись по дороге к Эльсинору» (Стоппард).

Получается, можно осторожно предположить, что исполнитель, актер в условиях представления находится в крайне интересном и противоречивом состоянии (которое уже не столь очевидно), подвергнут любопытным психофизическим и ментальным трансформациям, «растянут» на поверхности удивительного парадокса между наглядной, неустранимой искусственностью действия и этого же действия обратной потенцией - чем более оно выглядит естественным, спонтанным, «настоящим», тем больший эффект оно будет производить на зрителя (этого «онтологического свидетеля»). Есть в этой ситуации что-то «неухватываемое», ускользающее - некая тайна состояний «неадекватного», «обратного» человека театра.

\section{Границы театральной антропологии}

Самое время уточнить телеологию «Словаря театральной антропологии». Интерес его создателей сосредоточен как раз на изучении «физического самочувствия и поведения человека как живого существа в ситуации представления» (Барба, Саварезе, 2010: 8). Здесь надо бы по порядку.

Сформировавшаяся вокруг неусидчивого ученика Ежи Гротовского Эудженио Барбы международная школа театральной антропологии (International School of Theater Anthropology, далее - ISTA или Школа) за свою 25-летнюю историю передвижной театральной лаборатории собрала вокруг себя группу «ученых, специалистов по европейскому и азиатскому театру, apтистов, вышедших из разных актерских школ» (выделено мной. - С.К.) (Барба, Саварезе, 2010: 8). Относительно последних, думаю, необходимо обрисовать примерные контуры разброса этих школ: здесь представители условного обобщенного европейского театра, современной пантомимы, японских театров Но и Кабуки, ученик ученика Мейерхольда, исполнители балийских и индийских танцевальных представлений, современного балета, пекинской оперы и пр. Очевидно, такая «материальная база» уже сама по себе задавала уровень дерзновений: во-первых, попробовать, что называется, «обогатить» подходы к актерскому воплощению за счет интеркультурных взаимодействий и, во-вторых, постараться нащупать общие принципы организации сценической жизни (если таковые вдруг имеются), так сказать, «посмотреть широтой вглубь». Но, уточним, «делая акцент не на глубинных и гипотетических причинах их сходства, а на возможных способах их конкретного применения» (Барба, Саварезе, 2010: 9).

Результатом этого процесса, кроме всего прочего (вроде конкретных постановок и представлений), явилось его самоопределение как «театральной антропологии», в рамках которой продуцировались различные содержательные гипотезы, 
оформлявшиеся в статьи, книги, научные или околонаучные работы. А непосредственный объект нашего интереса, «Словарь театральной антропологии. Тайное искусство исполнителя» (далее - «Словарь») можно назвать «витриной» этого процесса, собравшей под своими створками ряд самых примечательных и основополагающих работ, размышлений. Цельность и некоторую фундаментальность «Словарю» придает тот факт, что это именно всамделишный словарь (главы располагаются в алфавитном порядке по первой букве их названия), то есть текстовое пространство, организованное, исключая лаконичные предисловие и вступление, не по принципу повествования-линии, а как мозаичная плоскость; можно даже пофантазировать, назвав его географической картой, картой области Театральная Антропология, где главы - острова или материки. Содержательно, несмотря на то что собственное целеполагание авторами выводится из простого вопроса, «какое направление следует избрать исполнителю, чтобы найти материальные основания своего искусства?» (Барба, Саварезе, 2010: 8), «Словарь» разрастается в явление, обладающее, как часто пишут в аннотациях к подобным книгам (и эта не исключение!) «широким историческим и культурным контекстом», грозя стать интересной «для всех, кто занимается вопросами искусства» (как пишут в тех же аннотациях). И это замечательно: человека хлебом не корми дай позаниматься вопросами искусства!

Уточняя смыслы театральной антропологии (в рамках и в понимании ISTA), Э. Барба на нескольких абзацах в предисловии и вступлении настойчиво отмежёвывается как от культурной антропологии, так и от претензий на строгую научность вообще.

«Единственное сходство между деятельностью ISTA и культурной антропологией - это изучение событий “явленных глазу” (как мы у себя их называем), связанных с перемещением, путешествием, стратегией огибания препятствий, что поз- воляет более точно понять собственную культуру. <...> Театральная антропология не является областью изучения зрелищной стороны тех событий и фактов, которые обычно изучают антропологи. Поэтому театральную антропологию не следует смешивать с антропологическим аспектом демонстрируемого зрелища. <..> Театральная антропология - это изучение поведения человеческого существа, использующего как инструмент свои психофизические свойства (свое присутствие) для некоей демонстрации, притом организованной в рамках предварительного замысла, не имеющего отношения к обыденной жизни. Театральная антропология не отыскивает общие истинные принципы, она собирает полезные указания. Она не скована самоуничижительным смирением науки, но заносчиво стремится отыскивать полезные для работы знания. Не жаждет обнаруживать “законы”, но наблюдает за правилами поведения» (Барба, Саварезе, 2010: 7-8).

А раз рассматриваемая нами деятельность связана с перемещением, путешествием, почему бы нам не подобрать эквивалент этим действиям в нашем рассмотрении и тоже не отправиться в своеобразное свободное путешествие по страницам «Словаря», тем более что мы уже успели представить его в виде карты. В качестве средства передвижения, правда, не остается ничего иного, кроме как моего непоседливого впечатлительного чувства, ну так, может, оно и к лучшему?

\section{«The paper canoe» ${ }^{1}:$ кодификация, технология, разрыв}

Театральное действие есть антропологическая перемена места - перемещение и путешествие внутри событийного театрального взаимодействия. Во всяком перемещении, изменении границ есть свой горизонт порядка - conditio sine qua non. Наивным было бы исключить «Словарь» из общей логики театральной антрополо-

${ }^{1}$ (Barba E. The paper canoe; cp.: Барба, 2008). 
гии, тем самым поставив Э. Барбу в неловкое положение внешнего наблюдателя, «антропологического посетителя с Марса» (Поппер, 2000: 99). «Словарь» наполнен фактичностью терминов, специфически использованным языком, индуцированными нерядовой, конкретной и растянутой во времени практикой, с предметностью чуждых нам традиций, кодифицирующими интерпретациями театральных явлений и анализом театральных технологий, направленных на «огибание препятствий» и т.п. «Ловушки интерпретации» для читателя словаря почти неизбежны, но - почему бы не позволить увлечь себя имманентной антропологией словаря? Ответить поиском возможных эквивалентов его театральной фактичности? ${ }^{2}$

Самое интересное и непривычное для русских читателей словаря место - театр Но. Элементы сцены, организующие это пространство: опорный столб, где стоит ваки (второй актер), лестница, ориентировочный столб (для актеров в масках), дверь для благородных персонажей, столб для флейтиста, столб для ситэ (первого актера), раздвижная дверца для выхода хора, боковая перегородка, перегородка-задник, на которой всегда нарисована сосна, столб для прислужника на сцене, столб для кёгена (комического актера), первая сосна, столб, отмечающий границу пространства, вторая сосна, третья сосна, окно, чтобы смотреть на сцену изнутри, занавесь, зеркало в «комнате с зеркалом», столб двери у занавеси, задняя перегородка моста (Барба, Саварезе, 2010: 89). Можно сказать, что это не место, а сплошной спойлер - если так выглядит любая конкретная площадка Но, если действие происходит в вечно идентичных «декорациях», перспектива неожиданных эффектных постановочных ходов заметно сужается и, резче говоря, возникает вопрос об адекватности самого термина «постановка».

2 О разнообразии подходов к исследованию театральной антропологии см., например: (Шестакова, 2008). Ср.: (Золотухин; Кухта, 2002; Новик, 2019; Отан-Матье).
Можно было бы также составить подобный перечень и относительно обязательных элементов сценического поведения исполнителей Но, того, что пока с осторожностью назовем актерской техникой. «Театр Но часто определяют как искусство ходить, художественный мир, созданный ногами. В театре Но основополагающую технику работы ног называют “суриаси” - “скольжение”. Скользя, можно идти, оборачиваться, топать. <..> В театре Но создан особый стиль ходьбы, тесно связанный с формой сцены, этот стиль и сейчас постоянно рафинируется, упорядочивается, что диктуется специфической значимостью выразительного языка ног. Но эти замечания относятся не только к театру Но, их можно применить и ко всему театральному искусству. В любых формах театра поступь должна пребывать в согласии с требованиями искусства» (Барба, Саварезе, 2010: 87).

Конечно, здесь мы уткнемся в некий здравый смысл, представляющий Восток как оплот традиции и упорядоченности, культуру повторения, в противоположность «пораженному духом изменчивости» Западу. Но вот нарочитое наставление Э. Барбы: нас не интересует «антропологический аспект демонстрируемого зрелища» и «как выстраивается так называемый театральный язык», нас интересует человек внутри сценической ситуации, его трансформации (на всех, а прежде всего на базовом - физиологическом - уровнях), то, чем они обусловлены, - в том числе, деятельной конкретностью его пространства, его ритмом, «пространством-во-времени» (семантика времени, похоже, приобретает в «ловушке интерпретации» Барбы картезианский оттенок, понимается не эсхатологично или количественно, а как сугубая длительность, протяженность телесного мира театрального действия) - соотношением идентичности конкретного спектакля к этим «принципам в традиции», положением «второй сосны», или же, сказать иначе, строго органичным набором правил 
поведения («органичным набором “советов первейшей важности"»).

Технологический момент примера Но - жесткая кодификация большинства элементов сценического действия: архитектура сцены, маршрут движения актера, походки, положение «однофункциональных» дверец, свойства сценических костюмов, «правильное вербальное поведение» и т.д. Подобным образом начинается и «Словарь» - с противопоставления исполнителей азиатского Востока (как носителей кодифицированной, «замкнутой в своих границах стилистики») и современного Запада (не располагающих в своей практике таким «набором добрых советов», вынужденных опираться только на текст, указания режиссера, какие-то обще-технические навыки, привитые в процессе обучения, если таковое было, индивидуальную «актерскую кухню»; здесь речь идет, конечно, в первую очередь, о драматических артистах). «Кодификация - это зримая последовательность неких физиологических процессов, происходящих в исполнителе, пытающемся расширить их; к кодификации прибегают для сохранения в нетронутом виде каких-то механических, динамических и силовых характеристик тех явлений, что мы наблюдаем в жизни. Кодификация - это формализация. Следовательно, в ней признали визуальные свойства, которые были дополнены “эстетической” ценностью» (Барба, Саварезе, 2010: 122). Код здесь, получается, - этакий кусок культурного слоя, который, в качестве инструмента актерской работы, в условиях непрерывной, «живой» традиции может помочь исполнителю создавать сиюминутные напряжения-связи с публикой (нечто слабо уловимое), так сказать, «поверх» непосредственного смысла и драматургии действия. Любопытен пример из истории внедрения мудр (жестов со специфическим положением кистей рук, имеющих религиозные корни) в искусство индийского танца, выступающих и как инструмент прямого повествования, и как «обеззначенный» элемент стилистики: «Но наиболее инте- ресные с точки зрения преэкспрессивности свойства мудр кроются в том, как их употребление (и сам принцип кодификации) соотносится с двумя основными категориями, на которые делится весь индийский театрализованный танец. В танцах-интерпретациях (нритья) мудры составляют тот истинный язык, о котором ранее шла речь. Они буквально представляют действие, раскрывая его сюжет и подробности. В так называемом чистом танце (нритта) все мудры, составляющие неотъемлемую часть повествования, напротив, приобретают декоративную ценность и употребляются как "простое звучание”. Кроме всего прочего, на основе кодификации с помощью четких символов (хаста/мудра: рука/печать) существует еще одна классификация приемов, называемая "хаста прана" (буквально: “жизнь рук”); в ней подразделяются основные позиции, в которых может оказаться рука $<\ldots>$ Именно эта выверенная пульсация, производимая постоянной сменой мускульных напряжений, обеспечивая динамический переход от одного значения к другому придает жизненную силу рукам актера и смысловую наполненность его исполнению вне границ какой-либо жесткой культурной кодификации» (Барба, Саварезе, 2010: 195).

В этом отрывке уже всплывает термин пре-экспрессивность. Здесь второй пункт противопоставления: в восточной традиции нет четкого разделения на специализации драматического, музыкального, балетного искусства, пантомимы. Авторы в своем рассмотрении преодолевают этот разрыв с «легкостью необыкновенной», не оставляя выбора - приходится принять способ их мышления как данность: «Все эти различия более или менее относительны, причем не только для нас. А потому пусть читатель не удивляется, что говоря о драматическом актере или о танцовщике, я не делаю между ними различия, равно как не усматриваю особой разницы в традициях Востока и Запада. $<\ldots>$ Жесткое разграничение театра и тан- 
ца, свойственное нашей культуре, свидетельствует о глубоком разрыве с предыдущей традицией, из-за которого современный драматический исполнитель чуть что рискует обречь свое тело на абсолютное молчание, а балетный актер - на сухую виртуозность. Напротив, подобное разграничение покажется совершенно абсурдным азиатскому актеру (настолько же, насколько оно показалось бы бессмысленным европейскому лицедею иных эпох, например, жонглеру раннего Средневековья или комедианту XVI века). Мы можем спросить у актера театра Но или Кабуки, как бы он перевел слово «энергия» на язык своего ремесла, но если мы попытаемся выяснить, в чем разница между театром и танцем, он только покачает головой» (Барба, Саварезе, 2010: 12).

«Словарь» населен множеством ассоциаций между сторонами воображаемого водораздела «Запад-Восток»; его авторы стремятся обнаружить подобные ассоциации на всех уровнях организации театрализованного зрелища: от элементарных геометрических, навеянных отдельными позами или жестами вне контекста, до полноценных «театрально-исторических» образований (с «нашей» стороны Барба сотоварищи ссылаются прежде всего на Комедию дель артэ, поскольку с исчезновением этой формы представления в 18 веке, если доверять авторам, как раз и связаны разделение на актеров/танцовщиков в Европе). Подтачивая, растушевывая эту границу, они отчасти смещают ее из области культурного антагонизма в область, так сказать, процессуальную, ситуацию «длящейся традиции», которая основывается на сложном взаимодействии учитель-ученик, непосредственной передаче уникальных и практических знаний (и здесь тоже находятся свои ассоциации), что, собственно, и позволяет использовать в подзаголовке «Словаря» слово «тайное». На противоположной же стороне, соответственно, оказывается прерывание «длящегося».
Мне кажется важным отметить, что Э. Барба и Н. Саварезе предостерегают от идеализации и мифологизации далёких как во времени так и пространстве форм театральности, будь то Комедия дель артэ, Древнегреческий театр или восточные представления во всём их многообразии (Барба, Саварезе, 2010: 33, 91). В этом смысле просто замечателен исторический казус, лежащий в основе одного из эффектных приемов театра Кабуки: актер замирает в «стоп-кадре» в пиковые моменты драматического напряжения - «обрезает миэ» (на сленге японских актеров). Миэ можно перевести как «указывать взглядом» (точный перевод - «видать»). Этот «стоп-кадр» должен зафиксировать состояние чрезмерного напряжения, в чем особую роль играет выражение лица и взгляд актера (для этого существует набор упражнений, тренирующих, собственно, смотрение). Дело в том, что раньше на вечерних представлениях в качестве освещения актера использовалась свеча, которой манипулировал служитель сцены с помощью приспособления в виде длинной жерди и чашечки. Таким образом, служитель не был виден, а актер практически всегда освещался - вот - в пределах света свечи, а поскольку почтенная японская публика во время представления в то время преимущественно занималась другим: пила чай, ела и беседовала, то исполнителям время от времени приходилось застывать в решающие моменты драмы, чтобы в этом полумраке до всех «докатился» накал момента и артистическая выразительность. Убогое освещение осталось в прошлом, а сам прием не отмер и оформился в органичную часть действа, и, сверх того, выступает свидетельством виртуозности исполнения. ${ }^{3}$

\section{«"Биологический" уровень зрелища» ${ }^{4}$}

В нашем умозрительном путешествии в антропологическое пространство

\footnotetext{
${ }^{3}$ (Барба, Саварезе, 2010: 64)

${ }^{4}$ (Барба, Саварезе, 2010: 7)
} 
«Словаря», между тем, все заметнее вездесущий инструмент сценической работы актерское тело. Сколь бы ни были актерские действия обусловлены «включенностью» в ту или иную знаковую или символическую систему, заданы неким кодом, интересны они здесь «низшим», физиологическим уровнем взаимодействий мышц, сухожилий, суставов. Нетрудно заметить, что и походка «суриаси» и применение мудр и миэ, в этом смысле, крайне неудобны, они создают избыточные (относительно обыденных) напряжения на этом элементарном уровне. Их можно охарактеризовать и как результат разнонаправленных (в том числе противоположно направленных) мышечных усилий. И то, и другое для исполнителя - само по себе таит потенцию действия, для зрителя - создает ощущение динамизма, повторюсь, на элементарном уровне (как физического, даже биологического присутствия актера, так и восприятия зрителя - авторы, в частности, используют термин «пре-интерпретация»). А коль скоро драма - суть действие, а драматургия - действие в развитии, вполне разумно присмотреться к возможностям его (действия) проявления и на этом малом уровне. «Ловушка интерпретации»: понятые чисто умозрительно, эти потенции рискуют обернуться «физкультурой», а не сценическим искусством; только «кирпичики» для конструирования чего-то можно, увлекшись, принять за «дом». Вычленить их как отдельный элемент возможно только на уровне отвлечения, ибо наглядно, как процесс, бытие актерского тела (как психофизического явления) цельно и, кроме того, органически (в идеале) встроено в несравнимо более сложную, комплексную целостность художественного произведения. В этом отвлечении позволительно говорить о сценическом биосе (некотором факте биологического присутствия исполнителя) - состоянии, которое учитывает и «работает» с этими «кирпичиками»-возможностями внутри сценической ситуации. Этот сценический биос в какомто смысле противоположен состоянию, определяющему повседневную, обыденную работу человеческого тела.

Чтобы определиться, в каком именно смысле можно с большей смелостью подойти к тому, что «Словарь» предлагает нам называть экстра-обыденной техникой владения телом, можно любой принцип существования в пределах театрального представления охарактеризовать как экстра-обыденный. Самое натуралистическое сценическое поведение никогда не будет идентичным поведению в обыденной жизни (в силу присутствия того самого «онтологического наблюдателя»); как минимум, оно будет необходимо подвержено «пропускам»: в жизни человеческий организм реагирует, зачастую одновременно, на множество раздражителей (в большинстве своем это микро-реакции, почти незаметные) - даже в моменты самых напряженных ситуаций мы, например, можем ощутить и параллельно отвлечься на легкое проявление сквозняка, незнакомый звук где-то вдалеке, урчание в собственном животе, внезапно пришедшую не относящуюся к делу мысль или образ из далекого прошлого, да просто почесать нос, что угодно (всё это едва заметные, но реальные изменения) - на подмостках большинство из них человек вынужден пропускать как лишние относительно сценического действия. Но экстра-обыденная техника должна обладать свойствами, не позволяющими, по слову Э. Барбы, обречь тело актера на безмолвие. Для этого она должна существовать в каком-то соотношении с техникой обыденного.

В «Словаре» для примера рассматривается такой ряд: обыденные техники повседневного поведения (обусловленные привычками, социальным и культурным контекстом), экстра-обыденная техника поведения на сцене и, третье, техника акробата или, как частность, исполнителя пекинской оперы. Последнее (акробатическая техника) является как бы проявлением «иного тела», непосредственно поражающего зрителя виртуозным использованием своих свойств (и остающегося на 
уровне «физкультуры»), его непохожесть на обычное использование тела, так сказать, естественна. Напротив, непохожесть поведения внутри театрализованной драматической ситуации неестественна, она может порождать напряжения в процессе восприятия, «возмущать» коммуникативное поле между исполнителем и публикой, которое так или иначе всегда возникает. И как раз способность использования этого «возмущения», этих «живых напряжений» как одно из свойств экстра-обыденной техники открывает какие-то сценические возможности в некоторой свободной, трансграничной перспективе. «Например, в театре Но второй исполнитель - ваки часто воплощает собственное несуществование, то есть отсутствие действия. С этой целью он прибегает к комплексной методике экстра-обыденной техники тела, которая “должна послужить не для воплощения чего-либо, а для того, чтобы сделалась заметной неспособность что-либо выразить". С подобным же отрицательным свойством мы сталкиваемся в тех эпизодах Но, где главный персонаж, ситэ, должен исчезнуть. И вот актер, перестав быть персонажем, но не прибегая к пластике обыденных телодвижений, отдаляется от зрителей - без желания что-либо им внушить, но с теми же энергетическими затратами, как и в моменты активного участия в действии» (Барба, Саварезе, 2010: 10).

Этот пример заодно иллюстрирует базовый принцип, отражающий «перевернутость» экстра-обыденного поведения избыточность (неоправданную в повседневности) энергетических затрат для выполнения даже простых действий. Это не подразумевает обязательно повышенную интенсивность телодвижений; скорее, наоборот. Собственно, в поиске простых, разнонаправленных мышечных напряжений, помогающих в этом жестов и поз, отыскиваются «центры энергетической работы». Для этого - суриаси, мудры и миэ. Главный «генератор напряженностей» актерского тела - позвоночник. Являясь центром, соединяющим эти усилия, он еще и организует их в масштабе целого организма. Хорошим «топливом» в этом процессе ему служит работа с равновесием - стремление к положениям неустойчивого равновесия, когда, нарушив баланс тела, чтобы не потерять его совсем, волей-неволей приходится «запустить» обратную силу. Этот несложный принцип ещё более наглядно проявляет то, что мы уже мельком затрагивали - динамизм, присущий природе сценического. Кроме того, сам позвоночный столб доступен для деформаций, являющихся источником «динамической формы» тела. «В Индии принцип оппозиции принимает весьма характерные формы как в танце, так и в фигуративных искусствах; его называют “три дуги”. Тело танцовщика приобретает контур латинской буквы "S" (голова, корпус, ноги) и оказывается в шатком равновесии, порождая очаги нового мускульного напряжения и создавая экстра-обыденную архитектуру тела» (Барба, Саварезе, 2010: 101; ср.: Bar$\mathrm{ba}, 1998)$. Принцип оппозиции уже может «развертываться» во времени, переходя в «танец оппозиций» (как его называют авторы), который, в сущности, способен стать фундаментом полноценное существование артиста. «Когда западный актер хочет выглядеть энергичным, когда он стремится выплеснуть всю свою энергию, он начинает перемещаться по сцене с максимальной витальностью. Он активно жестикулирует, его мускулы интенсивно напрягаются. Всё это ассоциируется с представлением об «усилиях», о «тяжком труде». Азиатский актер (или крупный западный мастер) может затрачивать гораздо больше сил, почти не двигаясь при этом. Его усталость будет обусловлена не чрезмерной сценической витальностью и жестикуляцией, но игрой разнонаправленных импульсов (оппозиций). Его тело заряжается энергией, поскольку в нем возникает множество напряжений от разницы потенциалов, и это придает ему жизненность, делает его присутствие ощутимым, даже когда движения медленны, а то и в моменты кажущейся неподвижности. Танец оп- 
позиций разыгрывается внутри тела, прежде чем вырваться вовне» (Барба, Саварезе, 2010: 13, 14).

\section{К актерскому присутствию}

Мы остаемся на элементарном, «биологическом» уровне рассмотрения именно потому, что он в ряду других уровней организации актерской работы (авторы выделяют три таковых: первый обусловлен индивидуальными опытом и набором «личностных» и психологических характеристик; второй задает способы проявления, исходящие из социокультурного контекста; третий основывается на использовании физиологических свойств - объект нашего конкретного интереса) не зависит от эпохи или состояния культуры, свойственен всем исполнителям (Барба, Саварезе, 2010: 7). Именно на нем, прежде всего, стоит пытаться выявить принципы, лежащие в основе сценической ситуации, в их применимости к работе над любым видом зрелища. Это попытка действительно нащупать материальные основы актерского сценического искусства. Речь не идет о выработке специального «эстетизированного поведения» (хотя постфактум это может считываться именно так), а скорее, о специфической простейшей взаимосвязи сцены и повседневности. Сценический биос исполнителя тогда можно рассматривать как эквивалент безусловной данности человеческого тела. Они противопоставлены по принципу затрат энергии: если наше повседневное тело (как раз в виду его безусловной данности) стремится к эффективному расходованию энергии - чем меньше затрат на выполнение задачи, тем лучше (в каком то смысле, оно, получается, мешает нам: вот бы совсем не затрачивать силы на решение задач!), то сценическое тело находит себя в тяге к ее избыточному выплеску. Момент переключения между этими «режимами» не очень очевиден - дело не в волевом усилии, точнее, не только в нем (в каких-то точках оно может и мешать), это вопрос комплекса порой совсем неочевидных усилий (и расслабле- ний). С этой целью, как мне видится, авторы и вводят термин пре-экспрессивности, выделяют сферу пре-экспрессивности как некоторый операционный уровень. «Преэкспрессивный уровень включает решение задачи, как сделать сценически живой актерскую энергию, то есть как она может превратиться в присутствие, самым непосредственным образом завоевывающее внимание зрителя. Вот где область изысканий театральной антропологии. Такой пре-экспрессивный субстрат включается как элемент в ту целостность, что называется экспрессией, и завоевывает внимание зрителя. Однако если в процессе подготовки роли всё рассматривать по отдельности, актер может вмешиваться в свою работу над ролью именно на этом преэкспрессивном уровне. Как если бы, пока длится такое вмешательство, главной целью становились бы энергия, присутствие, сценический биос и их проявления, а не тот смысл, который во всём этом таится» (Барба, Саварезе, 2010: 119).

Мы добрались, наконец, до «онтологического» центра театральной антропологии - актерского присутствия, в котором дает себя знать событийность сценического существования актера. Этот термин (использовавшийся еще К.С. Станиславским, ср.: (Аронсон, 2007)) - интригующий и семантически туманный, легко подверженный переинтерпретациям, - есть когнитивный образ качества актерского бытия. В сценическом присутствии - взаимодействие сторон, преодолевающих банальность миметического; в этом присутствии дает себя знать запрет на превращение актера в знаковую или символическую функцию. В онтологическое перспективе «Словаря театральной антропологии» разговор о проявлениях сценического человека не как автономного носителя абстрактных театральных смыслов, или, страшно сказать, не как инструмента спектакля, «технически воспроизводимого» (ср.: (Беньямин, 1996)) произведения искусства, в котором инструмент нуждается в правильном использовании, но как само- 
стоятельное явление, указующее на некоего рода иное, «обратное» жизненной реальности и само реальное актерское бытие.

\section{Литература}

Аронсон, О.В. Неоконченная полемика: биомеханика Мейерхольда или психотехника Станиславского? // Русская антропологическая школа. Труды. Вып. 1/4. М.: РГГУ, 2007. С. 410-423.

Барба, Э. Бумажное каноэ: Трактат о Театральной Антропологии. СПб.: Изд-во СПбГАТИ, 2008. 304 с.

Барба Э., Саварезе Н. Словарь театральной антропологии: тайное искусство исполнителя / пер. И. Васюченко, М. ДаксбуриАлександровской, Г. Зингера, Е. Кузиной. Москва: Артист. Режиссер. Театр, 2010. 318 с.

Беньямин, В. Произведение искусства в эпоху его технической воспроизводимости. М.: Медиум, 1996. 240 с.

Золотухин, В. «Словарь театральной антропологии» Эудженио Барбы: рецензия [Электронный pecypc] URL: http://os.colta.ru/theatre/events/details/20566 (дата обращения: 05.05.2019).

Кухта, Е. Театральная антропология как понимает ее Эуженио Барба // Петербургский театральный журнал. 2002. № 2 (28) [Электронный ресурс] URL: http://ptj.spb.ru/archive/28/teachers-

28/teatralnaya-antropologiya-

kakponimaeteeeuzheniobarba (дата обращения: 10.05.2019).

Новик, Ю.О. Антропологические основания концепции «театральной антропологии» Э. Барбы // Вестник Академии Русского балета им. А.Я. Вагановой. 2019. № 2 (61). С. 100113.

Отан-Матье, М-К. Первопроходцы театральной антропологии [Электронный ресурс] URL: http://nrgumis.ru/articles/147/ (дата обращения: 10.05.2019).

Поппер, К. Логика социальных наук // Эволюционная эпистемология и логика социальных наук: Карл Поппер и его критики / Сост. Д.Г. Лахути, В.Н. Садовского и В.К. Финна; пер. с англ. Д.Г. Лахути; вступ. ст. и общ. ред. В.Н. Садовского; послесл. В.К. Финна. М.: Эдиториал УРСС, 2000. С. 94105.

Стоппард, Т. Розенкранц и Гильденстерн мертвы [Электронный ресурс] URL:
http://lib.ru/PXESY/STOPPARD/r_g.txt_withbig-pictures.html (дата обращения: 10.05.2019).

Шестакова, А.В. Феномен «театральной антропологии» в европейской культуре второй половины XX века: автореф. ... канд. филос. наук. M., 2008 [Электронный ресурс] URL: http://cheloveknauka.com/fenomen-teatralnoyantropologii-v-evropeyskoy-kulture-vtoroypoloviny-xx-veka (дата обращения: 09.05.2019).

Barba, E. How to die standing // Total theatre. 1998. Vol. 10. No 3 [Online] URL: https://www.academia.edu/9501428/How_To_Die _Standing_-

_Carran_Waterfield_interviews_Eugenio_Barba_ 1998 (дата обращения: 01.03.2019).

Barba, E. The paper canoe. A Guide to Theatre Anthropology / Translated by Richard Fowler [Online] URL: http://asset.soup.io/asset/0826/4375_63b2.pdf (дата обращения: 01.03.2019).

\section{References}

Aronson, O.V. (2007), "The unfinished polemic: Meyerhold's biomechanics or Stanislavsky's psychotechnics?", Russkaya antropologicheskaya shkola. Trudy. Vypusk 1/4 [Russian anthropological school. Works. Issue 1/4], (1/4), RSUH, Moscow, Russia, 410-423 (in Russ.).

Barba, E. (1998), "How to die standing", Total theatre, 10 (3), [Online], available at: https://www.academia.edu/9501428/How_To_Die _Standing_-

_Carran_Waterfield_interviews_Eugenio_Barba_ 1998 (Accessed 01 March, 2019).

Barba, E. (2008), Bumazhnoe rfnoe: traktat o teatral'noy antropologii [The paper canoe. A Guide to Theatre Anthropology], Translated by Fowler, R., SPbGATI, Sankt-Petersburg, Russia (in Russ.).

Barba, E. The paper canoe. A Guide to Theatre Anthropology, Translated by Fowler, R. [Online], available at: http://asset.soup.io/asset/0826/4375_63b2.pdf (Accessed: 01 March, 2019).

Barba, E., Savarese, N. (2010), Slovar' teatral'noy antropologii: taynoe iskusstvo ispolnitelya [Dictionary of theatre anthropology: the secret art of the performer], Translated by Vasyuchenko, I., Artist. Rezhysser. Teatr, Moscow, Russia (in Russ.).

Benjamin, Walter (1996), Proizvedenie iskusstva $v$ epokhu ego tekhnicheskoy vosproizvodimosti [A work of art in the era of its tech- 
nical reproducibility], Medium, Moscow, Russia (in Russ.).

Kukhta, E. (2002), "Theatrical anthropology as it understood by Eugenio Barba", Peterburgskiy teatral'niy zhurnal, [Petersburg theatre magazine], 2 (28) [Online], available at: http://ptj.spb.ru/archive/28/teachers-

28/teatralnaya-antropologiya-

kakponimaeteeeuzheniobarba (Accessed 10 May, 2019) (in Russ.).

Novik, Y.O. (2019), "Anthropological foundation of the E. Barba's theatre anthropology concept", Vestnik Akademii russkogo baleta imeni A.Ya. Vaganovoy [Bulletin of Vaganova Ballet Academy], 2 (61), 100-113 (in Russ.).

Otan-Mat'e, M.-K. Pervoprokhodtsy teatral'noy antropologii [Pioneers of theatrical anthropology] [Online], available at: http://nrgumis.ru/articles/147/ (Accessed: 10 May, 2019) (in Russ.).

Popper, K. (2000), The Logic of Social Sciences, Evolutionary Epistemology and Logic of Social Sciences, Editorial URSS, Moscow, Russia, 94-105 (in Russ.).

Shestakova, A.V. (2008), "The phenomenon of "theatrical anthropology" in the European culture of the second half of the XX century", Abstract of Ph.D. dissertation, Moscow, Russia [Online], available at: http://cheloveknauka.com/fenomen-teatralnoyantropologii-v-evropeyskoy-kulture-vtoroypoloviny-xx-veka (Accessed 09 May, 2019) (in Russ.).
Stoppard, T. Rosencrantz i Guildenstern mertvy [Rosencrantz and Guildenstern are dead] [Online], available at: http://lib.ru/PXESY/STOPPARD/r_g.txt_withbig-pictures.html (Accessed: 10 May, 2019) (in Russ.).

Zolotukhin, V., Slovar' teatral'noy antropologii Eugenio Barby: retsenziya ["A dictionary of theatre anthropology" of Eugenio Barba: review] [Online], available at: http://os.colta.ru/theatre/events/details/20566 (Accessed: 05 May, 2019) (in Russ.).

\section{Информация о конфликте интересов:} автор не имеет конфликта интересов для деклараций.

Conflict of Interests: author has no conflict of interests to declare.

\section{OБ АВТОРE:}

Купчичев Сергей Сергеевич, актер Белгородского государственного академического театра драмы им. М. С. Щепкина, Соборная пл., д. 1, г. Белгород 308000, Россия; shamansss@mail.ru

\section{ABOUT THE AUTHOR:}

Sergey S. Kupchichev, an actor of Belgorod State Academic Drama Theater behalf of M. S. Schepkina, 1 Cathedral Sq., Belgorod 308000, Russia; shamansss@mail.ru 